\title{
CONTROL DE CONVENCIONALIDAD \\ ¿Puede la Corte Interamericana de Derechos Humanos dejar sin EFECTO Fallos de LOS TRIBUNALES SUPERIORES DE LOS PaÍses? (EL CASO FONTEVECCHIA VS. ARGENTINA)
}

Juan Carlos Hitters

I. Antecedentes.

A. Generalidades. Conflicto de competencias entre el supremo tribunal argentino y la Corte Interamericana de Derechos Humanos.

B. El caso Fontevecchia.

1. Sentencia de fondo y reparaciones.

2. Primera supervisión.

3. Segunda supervisión.

II. Contenido del fallo de la Corte Suprema Nacional del 14 de febrero de 2017 (caso “... Ministerio de Relaciones y Culto...”).
A. Postura de la mayoría de la Corte Nacional.
B. Postura concurrente del juez Rosatti.
C. Postura minoritaria del juez Maqueda.

III. Casos en los que la Corte IDH ha mandado a "dejar sin efecto" fallos locales.
A. Generalidades.
B. El caso Palamara Iribarne vs. Chile.
C. El caso Tristán Donoso vs. Panamá.
D. El caso Kimel vs. Argentina.
E. El caso Bueno Alvez vs. Argentina.
F. El caso Herrero Ulloa vs. Costa Rica.

IV. Es posible dejar sin efecto fallos domésticos. Argumentos del fallo argentino comentado.

V. Réplica.
A. Tratados clásicos y tratados sobre derechos humanos.
B. Kompetenz kompetenz.
C. Vuelta al dualismo.
D. El principio de subsidiariedad.
E. Margen de apreciación nacional. 
VI. Consecuencias jurídicas de la falta de anulación.

VII. La controvertida interpretación del tribunal supremo nacional.

VIII. Imposibilidad de incumplir un fallo de la Corte IDH. El caso Radilla Pacheco.

IX. Conclusiones.

\section{ANTECEDENTES}

\section{A. Generalidades. Conflicto de competencias entre el supremo tribunal argentino y la Corte Interamericana de Derechos Humanos}

El difícil problema que pretendemos poner de relieve es focalizar las facultades decisorias de la Corte Interamericana de Derecho Humanos (Corte IDH) en su relación con los supremos tribunales de los diversos países que se han plegado al modelo del Pacto de San José de Costa Rica.

Es decir, lo que buscamos saber es si aquel cuerpo regional estaría en condiciones de "dejar sin efecto" o "revocar" los pronunciamientos de las más altas cortes domésticas.

Esta cuestión se ha planteado recientemente en la Argentina, donde la Corte Suprema le disputa parte de la competencia al Tribunal Interamericano, sosteniendo que, si bien las sentencias de éste son obligatorias, dicho organismo no puede "casar" o "dejar sin efecto" decisiones judiciales locales.

Desanudar esta madeja es trascendente porque se discuten en definitiva las potestades de estos órganos; y en tal cuestión no se puede albergar hesitación alguna porque hace a la distribución de competencia de ambos tribunales, uno nacional y otro supranacional; y además implica resolver si para cumplir con los fallos interamericanos es necesaria una especie de "contralor previo" por parte de los más altos cuerpos jurisdiccionales domésticos.

\section{B. El caso Fontevecchia}

\section{Sentencia de fondo y reparaciones ${ }^{I}$}

Conviene aclarar previamente y de modo sintético, para luego desarrollar con mayor profundidad esta álgida cuestión, que la Corte Suprema de la Nación

1 Corte IDH, Caso Fontevecchia y D'Apost. Amico vs. Argentina, sentencia de 29 de noviembre de 2011, Serie C No 238. 
Argentina (CSJN), el 14 de febrero de $2017^{2}$, ha sostenido enfáticamente -por mayoría de fundamentos- que ella no puede ser obligada a acatar el fallo supranacional de "dejar sin efecto" un pronunciamiento doméstico".

Será importante poner de relieve que los tribunales argentinos habían condenado a la Editorial Perfil y a los directivos Jorge Fontevecchia y Héctor D'Amico, en el año 2001, haciendo lugar al pedimento del entonces presidente de la nación, Dr. Carlos Saúl Menem, por la infracción a su derecho a la intimidad con motivo de la publicación de dos artículos en el año 1995 en la Revista Noticias; ambos se referían a un presunto hijo no reconocido del primer mandatario, así como a la relación de este último con su madre.

Luego la Corte IDH puso énfasis en sostener que no hubo una injerencia arbitraria en el derecho a la vida privada del presidente, funcionario público electivo del más alto grado del país. Ello así, pues las publicaciones de marras constituyeron un ejercicio legítimo del derecho a la libre expresión, habida cuenta que se trataban de: 1) asuntos de interés público y 2) el presunto afectado no habia contribuido a resguardar la noticia cuya difusión a posteriori objetó.

Entendió entonces que al condenar a la revista y a los Sres. Fontevecchia y D'Amico se cometió el error al excluir de toda ponderación, en el caso concreto, los aspectos de interés público de la información.

Aquí queda en claro que la Corte IDH le imputó a la jurisdicción doméstica un déficit, al "no valorar tal cuestión esencial".

2 CSJN, 14 de febrero de 2017, 368/1998 (34-M)/CS1 Ministerio de Relaciones Exteriores y Culto s/ informe sentencia dictada para el caso "Fontevecchia y D'Amico vs. Argentina" por la Corte Interamericana de Derechos Humanos.

3 En tanto la Corte IDH resolvió “... Mantener abierto el procedimiento de supervisión de cumplimiento respecto de las medidas de reparación (...) relativas a: dejar sin efecto la condena civil impuesta a los señores Jorge Fontevecchia y Hector D'Amico así como todas sus consecuencias...”, conf. Corte IDH, Caso Fontevecchia y D'Amico vs. Argentina, Supervisión de Cumplimiento de Sentencia, Resolución de la Corte Interamericana de Derechos Humanos de 22 de noviembre de 2016. 


\section{Primera supervisión 4}

Como es sabido, el tribunal regional tiene la competencia de supervisar el cumplimiento ${ }^{5}$ de sus fallos ${ }^{6}$.

Por ello, el 19 de septiembre de 2015, ante la falta de acatamiento de alguna de las mandas impuestas en el proveimiento interamericano de 20117 , sostuvo éste que pasados dos años y ocho meses del pronunciamiento prístino, la Argentina no había informado respecto de implementación del acatamiento de la aludida sentencia ni presentó escrito alguno ${ }^{8}$, lo que implica un incumplimiento de la obligación de informar. Por esto dijo que, ante el silencio estatal, la supervisión debía continuar?.

4 Corte IDH, Caso Fontevecchia y D'Amico vs. Argentina, Supervisión de Cumplimiento de Sentencia, Resolución de la Corte Interamericana de Derechos Humanos de 1 de septiembre de 2015, ver párrs. 93 y 94.

5 Hitters, Juan Carlos, "Cumplimiento de las sentencias de la Corte Interamericana", en Revista La Ley, 6 de junio de 2012, p. 1.

${ }^{6}$ Dicha potestad surge de la propia jurisprudencia de la entidad jurisdiccional de marras, caso "Baena Ricardo y otros vs. Panamá", y además se desprende de los dispuesto en los artículos 33, 62.1, 62.3 y 65 de la Convención Americana de Derechos Humanos, artículo 30 de su Estatuto y 69 del Reglamento.

7 Corte IDH, Caso Fontevecchia, Sentencia de 29 de noviembre de 2011, cit.

8 Seńala la Corte en esta Supervisión de Cumplimiento que: "... los Estados Partes de la Convención Americana tienen la obligación convencional de implementar tanto a nivel internacional como interno y de forma pronta e íntegra, lo dispuesto por el Tribunal en las Sentencias que a ellos conciernan, obligación que, como lo señala el derecho internacional consuetudinario y lo ha recordado la Corte, vincula a todos los poderes y órganos estatales (Cfr. Caso Castillo Petruzzi Vs. Perú. Resolución de 17 de noviembre de 1999, Considerando tercero; Caso Baena Ricardo Vs. Panamá. Sentencia de 28 de noviembre de 2003. Serie C No 104, párr. 131, y Caso Masacres de Río Negro y Gudiel Alvarez. Resolución de 21 de agosto de 2014, Considerando sexto) y que, de no cumplirse, se incurre en un ilícito internacional. Al respecto, es menester ańadir que siempre, según el derecho internacional consuetudinario y lo afirmado por la Corte, al producirse un hecho ilícito atribuible a un Estado, surge la responsabilidad internacional de éste por violación de una norma internacional, dándose así origen a una relación jurídica nueva que consiste en la obligación de reparar (Cfr. Caso Garrido y Baigorria Vs. Argentina. Sentencia de 27 de agosto de 1998. Serie C No 39, párr. 40, y Supervisión conjunta de 11 casos Vs. Guatemala. Resolución de la Corte Interamericana de Derechos Humanos de 21 de agosto de 2014, Considerando sexto). Tal como ha indicado la Corte (Cfr. Caso Castillo Páez Vs. Perí. Sentencia de 27 de noviembre de 1998. Serie CNo 43, párr. 50, y Caso Cruz Sánchez Vs. Perí. Sentencia de 17 de abril de 2015, Serie C No 292, párr. 451.), el artículo 63.1 de la Convención reproduce el texto de una norma consuetudinaria que constituye uno de los principios fundamentales del derecho de la responsabilidad internacional de los Estados (Cfr. Supervisión conjunta de 11 casos Vs. Guatemala. Resolución del 21 de agosto de 2014, Considerando sexto)". Corte IDH, Caso Fontevecchia Supervisión de Cumplimiento, Resolución de 1 de septiembre de 2015, cit., Considerando quinto (Primera Supervisión).

9 Por ello resolvió: "1) Disponer que Argentina adopte, en definitiva y a la mayor brevedad posible, las medidas que sean necesarias para dar efectivo y pronto cumplimiento a las reparaciones dispuestas en la Sentencia de fondo, reparaciones y costas dictada en el presente caso, de acuerdo con lo estipulado en el 


\section{Segunda supervisión ${ }^{10}$}

Luego, el 22 de noviembre de 2016 consideró que, a esa fecha, el Estado había acatado la mayoría de los mandatos de la sentencia de 2011, salvo: a) dejar sin efecto la condena civil a los Sres. Jorge Fontevecchia y Héctor D'Amico y todas sus consecuencias (punto dispositivo $2^{\circ}$ de la Sentencia), y b) entregar en concepto de reintegro las sumas efectivamente pagadas, las costas y gastos de la etapa internacional ${ }^{11}$.

Por ello mantuvo abierto el proceso de supervisión y no cerró el caso.

\section{Contenido del fallo de la Corte Suprema Nacional del}

14 de febrero de 2017 (CAso “... Ministerio de Relaciones y Culto...”)

Para dejar perfectamente enfocada esta problemática no será ocioso llevar a cabo una pequeña explicación de los tramos de estas actuaciones que pasaron por tres tribunales locales, por la Comisión IDH y luego por la Corte IDH. En efecto, la demanda original fue desestimada en primera instancia. La Cámara Nacional de Apelaciones en lo Civil la revocó, y como consecuencia hizo lugar a la pretensión del entonces presidente Dr. Carlos Menem y condenó a la Revista Noticias y a los demandados ya aludidos, fijando un monto indemnizatorio. La Corte Suprema de la Nación, en su pronunciamiento del 25 de septiembre de 2001, ratificó la sentencia del a quo, sólo reduciendo la cuantía indemnizatoria.

Con posterioridad primero intervino la Comisión IDH y luego la Corte IDH en su fallo de fondo del 29 de noviembre de 2011, y en las dos supervisiones

artículo 68.1 de la Convención Americana sobre Derechos Humanos, 2) Disponer que el Estado presente a la Corte Interamericana de Derechos Humanos, a más tardar el 31 de marzo de 2016, un informe en el cual indique las medidas adoptadas para cumplir con las reparaciones ordenadas por esta Corte, de conformidad con la parte considerativa de esta Resolución, 3) Disponer que los representantes de las víctimas y la Comisión Interamericana de Derechos Humanos presenten observaciones al informe del Estado mencionado en el punto resolutivo anterior, en los plazos de cuatro y seis semanas, respectivamente, contados a partir de la recepción del informe, y 4) Disponer que la Secretaría de la Corte notifique la presente Resolución al Estado, a los representantes de las víctimas y a la Comisión Interamericana de Derechos Humanos", Corte IDH, Caso Fontevecchia Supervisión de Cumplimiento, Resolución de 1 de septiembre de 2015, cit., Resuelve, puntos 3, 4, 5 y 6 .

10 Corte IDH, Caso Fontevecchia y D'Amico vs. Argentina, Supervisión de Cumplimiento de Sentencia, Resolución de la Corte Interamericana de Derechos Humanos de 22 de noviembre de 2016.

11 Ver párrafos 105, 117, 128 y 129 de la sentencia Corte IDH, Caso Fontevecchia y D'Amico vs. Argentina, 2011. 
que ya aludimos, la primera de 1 de septiembre de 2015 y la segunda de 22 de noviembre de 2016.

La Corte regional ordenó entre otros tópicos que se debía: "a. Dejar sin efecto la condena civil impuesta a Jorge Fontevecchia y Héctor D'Amico, como asi también todas sus consecuencias..." 12 .

Este pronunciamiento fue parcialmente acatado por el sistema doméstico, salvo el apartado "a"., ya que el más alto tribunal de la nación, en su fallo de 14 de febrero de $2017^{13}$, expuso, por mayoría compuesta por los jueces Dr. Ricardo Lorenzetti, Dra. Elena Highton de Nolasco, Dr. Carlos Rosenkrantz, y el voto concordante del Dr. Horacio Rosatti, y con el voto disidente del Dr. Juan Carlos Maqueda, que el cuerpo interamericano "no puede dejar sin efecto la condena civil impuesta", pese a que señaló que las sentencias de la Corte IDH dictadas en procesos contenciosos contra el Estado Argentino son, en principio, de cumplimiento obligatorio. Empero añadió que "... Dicha obligatoriedad, sin embargo, alcanza únicamente a las sentencias de dictadas por el tribunal internacional dentro del marco de sus potestades remediales. En efecto, es con ese alcance que el Estado Argentino se ha obligado internacionalmente a acatar las decisiones de la Corte IDH..."14 (énfasis añadido).

En definitiva, la CSJN le negó a su par regional la potestad de revocar fallos domésticos de la más alta jerarquía local.

\section{A. Postura de la mayoria de la Corte Nacional}

En forma estenográfica corresponde reiterar que, según el más alto cuerpo jurisdiccional doméstico, éste no puede "dejar sin efecto la condena civil impuesta" habida cuenta que la Corte IDH carece de aptitud para disponer esta orden. Señaló en paralelo que dicho cuerpo interamericano no constituye una cuarta

\footnotetext{
12 Además dispuso publicar un resumen oficial de su sentencia elaborado por la Corte Suprema, por una sola vez, en el Diario Oficial y en un diario de amplia circulación nacional, así como publicar la sentencia completa de la Corte Interamericana en la página del Centro de Información Judicial de la Corte Suprema; y asimismo entregar sumas de dinero reconocidas como reintegro de los montos de condena oportunamente fijados en la sentencia de la Corte Suprema de Justicia, como de los correspondientes a las reparaciones admitidas en su decisión internacional (dańo material, gastos derivados del trámite del proceso interno como del procedimiento internacional).

13 CSJ 368/1998, Ministerio de Relaciones Exteriores y Culto s/ informe, (cit.).

14 CSJ 368/1998, Ministerio de Relaciones Exteriores y Culto s/ informe, (cit.), Cons. $6^{\circ}$.
} 
instancia que revise o anule decisiones judiciales estatales, dado que la jurisdicción es subsidiaria, coadyuvante y complementaria ${ }^{15}$.

Adunó en paralelo que la vía de "dejar sin efecto" una sentencia pasada en autoridad de cosa juzgada es "un mecanismo restitutivo que no se encuentra previsto en el texto convencional". Agregando que por definición los tribunales internacionales son de competencia limitada de la manera prescrita en los instrumentos que los han constituido.

"Dejar sin efecto" - añadió- equivale a "revocar" y que ese trámite está fuera de la competencia convencional.

Postuló en ese sentido que el artículo 63.1 de la Convención Americana de Derechos Humanos (CADH) no contempla este andarivel, que tampoco ha sido siquiera imaginado -dice- en los trabajos preparatorios de la Convención ${ }^{16}$.

"Dejar sin efecto" un decisorio de la CSJN con calidad de res judicata es uno de los supuestos en los que la restitución resulta jurídicamente imposible a la luz del artículo 27 de la Constitución Nacional, ya que dicha norma impone una esfera de reserva soberana ${ }^{17}$ que se denomina fórmula argentina, postulado este que no ha sido modificado en la Convención Constituyente de 1994.

Antes de seguir adelante conviene alertar que lo hasta acá expresado por la mayoría de la CSJN no resulta ser una novedad, ya que remarca en gran parte lo sostenido por los votos disidentes del los doctores Fayt y Boggiano en los autos Arancibia Clavel ${ }^{18}$, y repetido luego por el Dr. Fayt en su voto minoritario en "Espósito"19, entre otros ${ }^{20}$.

15 CSJ 368/1998, Ministerio de Relaciones Exteriores y Culto s/ informe, (cit.), cons. $8^{\circ}$.

16 Conferencia Especializada Interamericana sobre Derechos Humanos, San José, Costa Rica, 7-22 de noviembre de 1969, Actas y Documentos, Secretaría General, Organización de los Estados Americanos, Washington, D.C., OEA/Ser.K/XVI/1.2. Cfr. CSJ 368/1998, Ministerio de Relaciones Exteriores y Culto s/ informe, (cit.), cons. $14^{\circ}$.

17 CSJ 368/1998, Ministerio de Relaciones Exteriores y Culto s/ informe, (cit.), cons. $16^{\circ}$.

18 CSJN - 24.08.2004 - "Arancibia Clavel, Enrique Lautaro $s /$ homicidio calificado y asociación ilícita y otros - Causa No 259 ".

19 CSJN, E 224 - XXIX. 23 de diciembre de 2004, "Espósito, Miguel Ángel s/ incidente de prescripción de la acción penal promovido por su defensa-Bulacio, Walter David-".

20 Con respecto al incumplimiento de los tratados en el ámbito doméstico, la Argentina (CSJN. Expte. 1307/2003) fue condenada por primera vez por la Corte IDH (fallo del 28 de noviembre de 2002, "Cantos vs. Argentina") por violentar los artículos 1.1, 8 y 25 de la CADH. En efecto, el más alto órgano de justicia local no dio acatamiento al pronunciamiento supranacional con respecto a unas costas producidas en el derecho interno y a la reducción de los honorarios de los peritos y abogados intervinientes. Como respuesta de ello, el Superior Tribunal de la Argentina (en una sentencia dividida), ante el pedido del procurador 


\section{B. Postura concurrente del Juez Rosatti}

Este ministro -que fue miembro de la Convención Nacional Constituyente- se pliega a los argumentos de la mayoría, particularmente en lo que hace a la esfera de reserva soberana de nuestro país, añadiendo fundamentos propios ${ }^{21}$.

Para mientes en que "no se puede hacer prevalecer automáticamente y sin escrutinio alguno el derecho internacional -sea de fuente normativa o jurisprudencial-sobre el ordenamiento constitucional argentino, a los cuales los tratados internacionales (y con más razón la interpretación de dichos tratados) deben ajustarse y con los cuales debe guardar conformidad" 22 .

Esta interpretación, agrega, es reflejo de una fuerte tradición constitucional doméstica, tal como supo exponer Joaquín V. González: "Un tratado no puede tener la supremacía de la Constitución Nacional".

Señala que frase de la Corte IDH "dejar sin efecto" debe interpretarse de manera armónica con el ejercicio de la máxima potestad jurisdiccional instituida en el sistema republicano constituido por el ordenamiento constitucional argentino (artículos 1, 8 y 16), "no siendo posible concretar la revocación formal del decisorio nacional sin violentar lo dispuesto en los artículos 27 y 75 inc. $22^{\circ}$ de

nacional respecto a que se cumpla el fallo interamericano (esto es, reducir la paga de los emolumentos profesionales), sostuvo por mayoría que no podía disponer lo pedido porque de esa manera se afectaría el derecho de los terceros que no intervinieron en el pleito, y que además no podía afectarse a cosa juzgada local que había dispuesto un monto mayor. Allí el Dr. Maqueda, en su voto minoritario, puso de relieve que el Estado debía dar cumplimiento a las disposiciones de la Corte Interamericana por ser obligatorias. El 26 de agosto de 2010, al supervisar la Corte IDH dichas actuaciones, dispuso que el Estado debia adoptar Las medidas necesarias para dar cumplimiento pronto a los puntos resolutivos pendientes de acatamiento de la sentencia regional. Ésta todavía no ha sido cumplida por el derecho interno pese a que ha habido varias actuaciones para no violentar el fallo regional.

21 Señaló el juez Rosatti que "...a la luz de la obligación que surge del art. 68.1 de la CADH -que ha sido suscrita por la República Argentina y goza de jerarquía constitucional (art. 75, inciso $22^{\circ}$ de la Constitución Nacional), por la cual el Estado Nacional se compromete a cumplir con las decisiones de la Corte IDH en los procesos en que ha sido parte, corresponde poner de manifiesto lo siguiente: Con relación al inciso c) del considerando $2^{\circ}$, se ha informado a este tribunal que, por intermedio del Ministerio de Relaciones Exteriores, se encuentra en vías de cumplimiento la medida de reparación prevista en el punto 4 de la parte dispositiva del referido fallo, hecho que da cuenta del principio de ejecución de dicho punto del pronunciamiento internacional (véase fs. 23/24 del escrito 2869/2016; fs. 1 del escrito 3201/2016). Con relación al inciso b) del considerando $2^{\circ}$, el 22 de noviembre de 2016 la Corte IOB declaró que el Estado argentino dio cumplimiento total a la medida de reparación ordenada en el punto 3 de su sentencia, relativa a la realización de las publicaciones del pronunciamiento internacional y del resumen oficial en los medios allí contemplados". Cfr. CSJ 368/1998, Ministerio de Relaciones Exteriores y Culto s/ informe, (cit.), Voto del Dr. Rosatti, cons. $4^{\circ}$.

22 CSJ 368/1998, Ministerio de Relaciones Exteriores y Culto s/ informe, (cit.), Voto del Dr. Rosatti, cons. $5^{\circ}$. 
la Constitución Nacional Argentina, cláusulas por cuya observancia esta Corte debe velar"23.

\section{Postura minoritaria del juez Maqueda}

El ministro referido en el epígrafe -que también integró la Convención Constituyente de 1994- se pone, en alguna medida, en las antípodas de sus colegas: entiende que los decisorios de la Corte Interamericana deben cumplirse en su totalidad.

Por ello, siguiendo a pies juntillas los fundamentos de la Corte IDH en el caso "Fontevecchia", sostiene justamente que corresponde "dejar sin efecto" la anterior decisión de la Corte nacional fallada con otra composición.

El Dr. Maqueda, coherentemente con sus opiniones anteriores, en su lúcido voto discrepa con los jueces de la mayoría, pues siendo las sentencias del organismo interamericano "obligatorias" y "vinculantes" en el ámbito de su competencia, no acatarlas-dice-implica una infracción convencional (art. 27 de la Convención de Viena sobre el Derecho de los Tratados) ${ }^{24}$. Además, explica que negarse a dejarlas $\sin$ efecto evita cuestionamientos futuros (cons. $6^{\circ}$ ).

\section{Casos en los QUe la Corte IDH HA MANDADO A "DEJAR SIN EFECTO" FALLOS LOCALES}

\section{A. Generalidades}

Si bien es por demás sabido que los órganos judiciales pueden -y a veces deben- modificar su jurisprudencia cuando resulte necesario, no lo es menos que en este asunto la CSJN se pasó a las antípodas, concretando una doctrina que nos parece muy endeble.

En verdad, lo resuelto en "Fontevecchia" por el tribunal del Pacto no es una novedad, ya que ha habido otros precedentes del mismo cuerpo en sentido similar.

Antes que nada -y para evitar confusiones-, hay que tener bien en cuenta que en este trabajo estamos hablando de casos en que el tribunal de Costa Rica ha dejado sin efecto sentencias, pues, como parece una obviedad, en muchísimos

\footnotetext{
23 CSJ 368/1998, Ministerio de Relaciones Exteriores y Culto s/ informe, (cit.), voto del Dr. Rosatti, cons. $8^{\circ}$. 24 CSJ 368/1998, Ministerio de Relaciones Exteriores y Culto s/ informe, (cit.), voto del Dr. Maqueda, cons. $4^{\circ}$ y $5^{\circ}$.
} 
otros asuntos mandó a dejar sin efecto, "prácticas", "normas" y "leyes" violatorias de la Convención ${ }^{25}$.

Vamos a traer a colación algunos asuntos sobre el particular sin pretender agotar los casos.

\section{B. El caso Palamara Iribarne vs. Chile 26}

En el fallo citado en el epígrafe, la Corte IDH determinó que los procesos llevados a cabo en la jurisdicción "penal" militar en contra de la víctima no tuvieron las garantías de competencia, imparcialidad e independencia necesarias en un Estado democrático; el país debe "dejar sin efecto" en el plazo de seis meses la sentencia emitida por la Corte Marcial de la armada chilena por el delito de desacato ${ }^{27}$.

Esta sentencia espeja una saga de pronunciamientos -sobre todo de México-de ese tribunal donde fustigó la posibilidad de que los cuerpos judiciales castrenses juzguen a civiles por delitos comunes ${ }^{28}$.

Importa alertar que Chile finalmente cumplió con el mandato de "dejar sin efecto en todos sus extremos las sentencias condenatorias emitidas en contra del señor Humberto Palamara" 29 (quien fue la víctima) ${ }^{30}$.

25 Ferrer Mac-Gregor, Eduardo "Interpretación conforme y control difuso de convencionalidad. El nuevo paradigma para el juez mexicano", en Carbonel y Salazar (Coordinadores), Derechos Humanos: un nuevo modelo constitucional, México, UNAM, II. J., 2011, pp. 339-429. Ídem Ferrer MAC-Gregor, Eduardo, Coordinador, "Interpretación conforme y control difuso de convencionalidad. El nuevo paradigma para el juez mexicano", en El control difuso de convencionalidad. Dialogo entre la Corte Interamericana de Derechos Humanos y los jueces nacionales, Fundap, México, 2012, p. 163.

26 Corte IDH, Caso Palamara Iribarne vs. Chile, sentencia de 22 de noviembre de 2005 . Serie C No 135.

27 Corte IDH, Caso Palamara Iribarne vs. Chile, (cit.), párr. 253.

28 Como bien dice la jurista chilena María José Eva Parada (Chile ante el sistema interamericano, el caso Palamara, Anuario de Derechos Humanos, Universidad de Chile, repositorio.uchile.cl, 2006), el fallo es de gran importancia para ese país, pues entre otras cosas exige adecuar el ordenamiento interno no sólo en lo que señala con relación a las leyes de desacato, sino también en lo que respecta a la justicia militar. En ese orden de ideas, la ley No 20.477, de 22 de noviembre de 2016, restringió la competencia de los tribunales militares de la forma aquí indicada.

29 Corte IDH. Caso Palamara Iribarne vs. Chile. Supervisión de Cumplimiento de Sentencia. Resolución de la Corte Interamericana de Derechos Humanos de 1 de septiembre de 2016.

30 Véase CEJIL, Corte Interamericana de Derechos Humanos dictó resolución en relación con el caso Palamara Iribarne vs. Chile, de 27 de agosto de 2009. 
Sin duda que la solución aquí brindada no podía ser enfocada de otra manera, ya que se trataba de una sentencia de un Tribunal Penal Militar totalmente incompetente y parcial.

\section{El caso Tristán Donoso vs. Panamá31}

Otro ejemplo de esta matriz lo podemos ver en "Tristán Donoso vs. Panamá", donde finalmente la Corte IDH condenó a "dejar sin efecto" una sentencia penal por violentar el Pacto de San José de Costa Rica.

La víctima, Santander Tristán Donoso, trabajaba en el año 1996 como asesor legal de una diócesis y en paralelo como abogado litigante y defensor. En su momento tuvo una conversación telefónica privada con su cliente que fue interceptada y grabada subrepticiamente, de donde surgiría prima facie que el procurador general de la nación habría recibido en el año 1994 un dinero en calidad de donación de dudosa procedencia. Dicho funcionario público divulgó el contenido y debido a ello el letrado aludido finalmente fue condenado por el delito de injurias.

Ante tal situación, luego de agotar los recursos internos, patrocinado por el Cejil promovió la denuncia ante la Comisión Interamericana de Derechos Humanos (Comisión IDH), que luego llegó a la Corte IDH. El tribunal regional, con fecha 21 de enero de 2009, condenó al Estado a "... dejar sin efecto la condena penal (...) y todas las consecuencias que de ella se deriven, en el plazo de un año contado a partir de la notificación de la presente sentencia..."32 (énfasis añadido).

En cumplimiento de lo dispuesto por la Corte IDH, la Sala Segunda de lo Penal de la Corte Suprema de Justicia (CCSJ) de Panamá absolvió al mencionado letrado de los cargos como autor del delito de calumnias y dejó sin efecto las penas impuestas de dieciocho meses de prisión, la inhabilitación para el ejercicio de

31 Corte IDH, Caso Tristán Donoso Vs. Panamá, Sentencia de 27 de enero de 2009, Serie C No 193.

32 Dijo allí: "Esta Corte ha determinado que la sanción penal emitida en contra del señor Tristán Donoso afectó su derecho a la libertad de expresión (supra párr. 130). Por lo tanto el Tribunal dispone que, conforme a su jurisprudencia, el Estado debe dejar sin efecto dicha sentencia en todos sus extremos, incluyendo los alcances que ésta pudiere tener respecto de terceros, a saber: a) la calificación del señor Tristán Donoso como autor del delito de calumnia; b) la imposición de la pena de 18 meses de prisión (reemplazada por 75 díasmulta); c) la inhabilitación para el ejercicio de funciones públicas por igual término; d) la indemnización civil pendiente de determinación; y e) la inclusión de su nombre de cualquier registro penal. Para ello, el Estado cuenta con un plazo de un ańo contado a partir de la notificación de la presente Sentencia”. Corte IDH, Caso Tristán Donoso Vs. Panamá, (cit.), párr. 195; ibídem Puntos Resolutivos, Disposición 14. 
cargos públicos y el pago de la indemnización civil por el daño material causado a la víctima.

Por todo ello, en la supervisión ${ }^{33}$ de 1 de septiembre de 2010 la Corte IDH dio por cumplido en forma total los puntos resolutivos de la sentencia ya aludida $\mathrm{y}$ archivó las actuaciones ${ }^{34}$.

Obsérvese que el máximo órgano de justicia de Panamá, en su Sala Segunda, acató sin ambages lo dispuesto por la Corte regional, "dejó sin efecto" la providencia condenatoria, basándose exclusivamente en el mandato de la Corte IDH.

\section{El caso Kimel vs. Argentina ${ }^{35}$}

Eduardo Kimel era un conocido periodista de investigación, quien escribió el libro La masacre de San Fatricio, ocurrida durante la dictadura militar argentina, el día 4 de julio de 1976. Allí se aludía a un asesinato de cinco religiosos de la Orden de los Palotinos. El actor criticó la actuación de las autoridades encargadas de la investigación y al juez en particular. El magistrado promovió una querella criminal de la cual resultó condenado en primera instancia Kimel a un año de prisión en suspenso y una multa de veinte mil pesos.

Resulta preciso señalar, para entender en pocas líneas, el trámite de estas actuaciones que transitaron por el derecho interno, luego por la Comisión IDH y, por último, en la Corte IDH.

Allí, la Sala VI de la Cámara Nacional de Apelaciones en lo Criminal y Correccional de la Capital Federal había absuelto en 1996 -por mayoría - al Sr. Kimel. Sin embargo, la Corte Suprema Nacional, también por mayoría, con fecha 22 de diciembre de $1998^{36}$, revocó la sentencia absolutoria de segunda instancia y remitió la causa a la Cámara Nacional de Apelaciones en lo Criminal para que dictara una nueva sentencia. El máximo órgano jurisdiccional nacional considero que la decisión había sido arbitraria.

Después, el 17 de marzo de 1999 la Sala IV, siguiendo los lineamientos de la Corte doméstica, confirmó parcialmente la decisión condenatoria de primera

33 Corte IDH. Caso Tristán Donoso vs. Panamá. Supervisión de Cumplimiento de Sentencia. Resolución de la Corte Interamericana de Derechos Humanos, 1 de septiembre de 2010.

34 Con fecha 1 de septiembre de 2010.

35 Corte IDH, Caso Kimel vs. Argentina, Sentencia de 2 de mayo de 2008, Serie C No 177.

36 CSJN Fallos 321-3596. 
instancia en lo que respecta a las penas, pero en vez de sentenciar al Sr. Kimel por injurias, entendió que se había configurado el delito de calumnias.

Contra la providencia de alzada, el afectado interpuso un recurso extraordinario ante la Corte Suprema Nacional, que fue rechazado, lo mismo que una queja, que también fue desestimada, por lo que la condena quedó firme en el campo argentino el 14 de septiembre de 2000.

Ya en la instancia supranacional, el tribunal interamericano el 2 de mayo de 2008 concluyó, entre otros temas, que el Estado debe dejar sin efecto la condena penal impuesta a Kimel y todas las consecuencias que de ella se deriven, en el plazo de seis meses a partir de la notificación de la sentencia.

Luego -y otra vez al ámbito doméstico-, el pronunciamiento de la Sala IV aludido fue atacado por vía del recurso de revisión, y resuelto el 10 de noviembre de $2011^{37}$, el que se apontocó en dos pilares: 1) el fallo de la Corte IDH que había mandado dejar sin efecto la sentencia, y 2) que la modificación legal dispuesta por la ley argentina No $26.551^{38}$ de los tipos penales en las que se basó la postura condenatoria, habilita el recurso de revisión (artículo 479 inc. $5^{\circ}$ del Código Procesal Penal). Ante dicha petición, el fiscal general y la Secretaría de Derechos Humanos de la Nación, en su calidad de "Amigo del Tribunal", aceptaron que se haga lugar al recurso de revisión.

En base a ello, dicha Sala de la Cámara Nacional de Casación Penal, y basándose más en la modificación legislativa que en el fallo de la Corte IDH, hizo lugar al recurso de revisión y dejó sin efecto el pronunciamiento condenatorio, acatando de ese modo el decisorio interamericano del 2 de mayo de 2008.

37 Causa No 13.272, Fallo de la Sala III, C.N. P. "Kimel, Eduardo Gabriel sobre recurso de revisión”, registro 17.08.2011.

38 Cabe enfatizar que, como consecuencia del tránsito supranacional del caso Kimel, se sancionó el 18 de noviembre de 2009 la ley No 26.551, que modificó parcialmente el Código Penal del país. Por el artículo $1^{\circ}$ de dicha norma legislativa se sustituyó el artículo 109 por el siguiente texto: "la calumnia o falsa imputación a una persona física determinada de la comisión de un delito concreto y circunstanciado que dé lugar a la acción pública, será reprimida por multa de pesos tres mil (\$3.000) a pesos treinta mil (\$30.000). En ningún caso configurarán delito de calumnia las expresiones referidas a asuntos de interés público o las cuales no sean asertivas". El artículo $2^{\circ}$ de dicha ley modificó el artículo 110 del siguiente modo: "el que intencionalmente deshonrare o desacreditare a una persona física determinada será reprimido con multa de pesos mil quinientos $(\$ 1.500)$ a pesos veinte mil $(\$ 20.000)$. En ningún caso configurarán delito de injurias las expresiones referidas a asuntos de interés público o las que no sean asertivas tampoco configurarán delito de injurias los calificativos lesivos del honor cuando guardas en relación con un asunto de interés público". 
Finalmente, la Corte IDH, luego de tres supervisiones, declaró que el Estado argentino ha dado total cumplimiento a la obligación de dejar sin efecto la condena penal por lo que decidió archivar el expediente ${ }^{39}$.

Se advierte aquí que el Poder Judicial doméstico, por vía indirecta (a través del recurso de revisión), dejó sin efecto una sentencia local, que esta vez no había sido dictada por la Corte Suprema, sino por un tribunal inferior.

\section{E. El caso Bueno Alves vs. Argentina ${ }^{40}$}

En el caso aludido en el epígrafe, tramitado durante la época democrática en Argentina (1988), fue detenido Bueno Alves, quien denunció casos de tortura. Como consecuencia de ello se condenó a René Jesús Derecho por el delito de torturas de las que había resultado víctima también Pérez Galindo, siendo el caso sobreseído por el tribunal supremo argentino como consecuencia de haberse declarado extinguida la acción penal por prescripción ${ }^{41}$.

Contra el fallo, y en las mismas actuaciones, el Sr. Pérez Galindo -como querellante- dedujo un recurso de aclaratoria, vía que fue recalificada por la Corte Suprema como "recurso de revocatoria". Este cuerpo hizo lugar a tal planteo -por mayoría- 42 citando expresamente las consideraciones expuestas en el precedente "Espósito" 33 . En consecuencia, sin más argumentación que la referencia al caso

\footnotetext{
39 El pronunciamiento fue el siguiente: “... Declara que: El Estado ha dado cumplimiento total a la obligación de dejar sin efecto la condena penal impuesta al seńor Kimel y todas las consecuencias que de ella se deriven (punto resolutivo séptimo de la sentencia), de conformidad con lo seńalado en los considerandos noveno a décimo tercero de la presente resolución. Y resuelve: 1 . Dar por concluido el caso Kimel, dado que la República Argentina ha dado cumplimiento íntegro a lo dispuesto en la sentencia emitida por la Corte Interamericana de Derechos Humanos el 2 de mayo de 2008. 2. Archivar el expediente del presente caso. 3. Comunicar esta resolución a la Asamblea General de la Organización de los Estados Americanos por conducto del Informe Anual de la Corte Interamericana de Derechos Humanos del ańo 2013. 4. Que la Secretaría de la Corte Interamericana de Derechos Humanos notifique la presente resolución a la República Argentina, a los representantes de los familiares de la víctima y a la Comisión Interamericana de Derechos Humanos...". Corte IDH, Caso Kimel vs. Argentina, Supervisión de Cumplimiento de Sentencia, Resolución de la Corte Interamericana de Derechos Humanos de 5 de febrero de 2013.

40 Corte IDH, Caso Bueno Alves vs. Argentina, Sentencia de 11 de mayo de 2007, Serie C No 164.

41 Corte Suprema de Justicia de la Nación, Derecho, René Jesús s/ incidente de prescripción de la acción penal -causa No 24.079-. D. 1682. XL. Sentencia 29 de noviembre de 2011.

42 Con los sufragios de los jueces Highton de Nolasco, Petracchi, Zaffaroni y Maqueda según su voto, y con las disidencias de los jueces Faty y Argibay, quienes propusieron hacer lugar a la prescripción.

43 CSJN. Caso "Espósito", ańo 2004. Fallos: 327:5668.
} 
Bulacio, le dio cabida a la revocatoria, dejando sin efecto el fallo de la propia Corte y devolviendo las actuaciones al tribunal de origen ${ }^{44}$.

\section{F. El caso Herrero Ulloa vs. Costa Rica}

El caso Herrera Ulloa ${ }^{45}$ tiene una gran similitud con el asunto "Fontevecchia". Mauricio Herrera Ulloa fue condenado por vía penal y civil en el derecho interno costarricense a raíz de varias publicaciones. Se trató de un periodista que trabajaba en el diario local La Nación, que publicó, en su momento, un grupo de artículos en los cuales denunciaba por diversas conductas ilícitas a un funcionario, Félix Przedborski, que representaba a dicha nación ante un organismo supranacional, la Organización Internacional de Energía Atómica (Euraton).

Este último incoo en mayo de 1995 dos querellas por "delitos de difamación, calumnias y publicaciones ofensas". Herrera Ulloa finalmente fue condenado por el máximo tribunal de justicia del país, lo mismo que la empresa periodística donde trabajaba.

Posteriormente, la Corte IDH sancionó al Estado de marras considerando que en el territorio aludido no estaba prevista la doble instancia en materia penal, de conformidad con el artículo 8.2.h del Pacto de San José de Costa Rica, y existiendo otras irregularidades al debido proceso legal. Sostuvo que se debía dejar sin efecto en todos los extremos la sentencia penal condenatoria.

En la supervisión de sentencia del 22 de noviembre del 2010, la Corte IDH señaló que Costa Rica cumplió a cabalidad con el fallo.

Adviértase que en este asunto en el derecho interno en lugar de "anular" literalmente la decisión condenatoria y sus consecuencias, el Estado acató las órdenes de la siguiente manera: 1.- Por medio del Juzgado Contencioso Administrativo ordenó la cancelación de los intereses etc., y 2.- En cuanto a las costas, a través de un Tribunal Constitucional Administrativo puso a disposición del diario $L a$ Nación los fondos pertinentes ${ }^{46}$.

\footnotetext{
44 La Corte IDH, en su supervisión de sentencia del 5 de julio de 2011, dispuso entre otras cosas realizar las debidas investigaciones para determinar las correspondientes responsabilidades por los hechos de este caso y aplicar las consecuencias que la ley prevea (punto 3.b).

45 Corte IDH, Caso Herrera Ulloa vs. Costa Rica, Sentencia de 2 de julio de 2004, Serie C No 107.

46 Sobre el particular dijo el Tribunal: “... Con respecto a la obligación de dejar sin efecto, en todos sus extremos, la sentencia emitida el 12 de noviembre de 1999 por el Tribunal Penal del Primer Circuito Judicial de San José (punto resolutivo cuarto de la sentencia), el Estado informó lo siguiente: a) sobre la suma adeudada por intereses, el Juzgado Contencioso Administrativo y Civil de Hacienda aprobó, mediante
} 
No va a resultar ocioso puntualizar que, a causa de ello, ese cuerpo judicial interamericano dio por cerrado el caso y archivó las actuaciones ${ }^{47}$.

Obsérvese que ni el Estado en general, ni el Poder Judicial en particular hicieron objeciones algunas a la posibilidad de "dejar sin efecto" fallos domésticos, no se cuestionó entonces - como hizo la CSJN Argentina- las potestades del órgano regional.

De paso debemos tener presente que no fue el tribunal superior el que cumplió el fallo, sino otros órganos del ámbito doméstico.

\section{ES POSIBLE DEJAR SIN EFECTO FALLOS DOMÉSTICOS}

\section{Argumentos del fallo argentino comentado}

Como anticipamos, el pronunciamiento bajo análisis, si bien implicó un tratamiento meduloso de la cuestión que venimos enfocando, consideramos que la mayoría se ha apegado demasiado al dualismo, minimizando de algún modo las potestades de la Corte IDH en lo que tiene que ver con los artículos 62 inc. $3^{\circ} \mathrm{y}$ 68 de la CADH. Fluye de la postura mayoritaria que, si bien los pronunciamientos de ese órgano jurisdiccional regional son obligatorios, no pueden ordenarle a la más alta jerarquia judicial doméstica cazar, anular o dejar sin efecto sentencias.

resolución de 8 de septiembre de 2009, la cancelación de intereses legales y moratorios por un monto de \$8.447.457,44 colones, el cual fue depositado a favor de La Nación el 13 de noviembre de 2009, y b) en cuanto al monto adeudado por costas personales, el Tribunal Contencioso Administrativo, Sección Primera del Segundo Circuito Judicial de San José, aprobó por medio de resolución de 23 de febrero de 2010 la suma de $\$ 422.372,87$ colones, la cual 'se encuentra a disposición de la empresa para ser girada contra el fondo de costas que el Estado mantiene para este fin'. Asimismo, señaló que ha solicitado la gestión de los trámites correspondientes para que dicho monto sea depositado en la cuenta bancaria de la empresa. Por lo anterior, el Estado consideró que 'ha satisfecho las obligaciones derivadas de la Sentencia de 2 de julio de 2004, motivo por el cual solicitó que se declare el cumplimiento definitivo en este aspecto'", Corte IDH, Caso Herrera Ulloa vs. Costa Rica, Supervisión de Cumplimiento de Sentencia, Resolución de la Corte Interamericana de Derechos Humanos de 22 de noviembre de 2010, párr. 7.

47 En tal sentido resolvió: “... 1. Dar por concluido el caso Herrera Ulloa, dado que la República de Costa Rica ha dado cumplimiento íntegro a lo ordenado en la Sentencia emitida por la Corte Interamericana de Derechos Humanos el 2 de julio de 2004; 2. Archivar el expediente del presente caso; 3. Comunicar esta Resolución a la Asamblea General de la Organización de los Estados Americanos en su próximo período ordinario de sesiones por conducto del Informe Anual de la Corte Interamericana de Derechos Humanos del año 2010; y 4. Requerir a la Secretaría de la Corte Interamericana de Derechos Humanos que notifique la presente Resolución a la República de Costa Rica, a la Comisión Interamericana de Derechos Humanos y a los representantes de la víctima", Corte IDH, Caso Herrera Ulloa vs. Costa Rica, Supervisión de Cumplimiento de Sentencia, 22 de noviembre de 2010 , cit., puntos resolutivos. 
Lo que importa aquí no es tanto el incumplimiento de la CSJN, sino los principios que fijó el fallo, lo que puede significar un paso atrás para la Argentina en el ámbito de los derechos humanos y en el control de convencionalidad ${ }^{48}$.

Se parte del artículo 27 de la Constitución Nacional, que señala que los tratados con las potencias extranjeras deben estar en conformidad con los principios de derecho público establecidos por la Carta Magna. Parece surgir de ese postulado un debate que todavía continúa sobre la prioridad de la Constitución con respecto a los tratados internacionales y viceversa. Por ello, el pronunciamiento de marras parte de la idea de que la jurisdicción supranacional tiene una esencia "subsidiaria" y que nuestro tribunal "supremo" nacional, por su carácter de tal, no puede recibir órdenes del cuerpo jurisdiccional interamericano.

Lo que debe quedar bien en claro es que los fallos de la Corte IDH tienen como fuentes el ius cogens (la costumbre internacional), y los tratados sobre derechos humanos, que como vemos son de distinta esencia que los tratados entre dos Estados.

De allí que, según nuestra posición, el artículo 27 de la Constitución Nacional obviamente no tuvo en miras - considerando la época- los tratados sobre derechos humanos que implican una cesión parcial de la soberanía cuando el Estado se adhiere a ellos; porque la Corte IDH no es un tribunal extranjero, sino que forma una soldadura indestructible entre el derecho interno y el derecho internacional.

Siendo ello así, puede ser que la Corte IDH haya utilizado en varias oportunidades la frase "dejar sin efecto" de manera no muy feliz en su aspecto terminológico, ya que en lugar de sostener eso, pudo decir que el derecho doméstico se adapte a la convención, sin aludir a esa expresión (“dejar sin efecto”), que lleva a posturas ríspidas en el campo local. Por ello pensamos que en el futuro debería adaptarse esta fraseología sin mutar su esencia.

Lo cierto es que las cuestiones sub examine llegan al tribunal supremo argentino vía un oficio de la cancillería (Dirección General de Derechos Humanos) para que ese cuerpo "... cumpla en lo que corresponda y de conformidad con su competencia, con la sentencia publicada por la Corte Interamericana.”..(párr. $4^{\circ}$ ).

Recuérdese que la Corte IDH había dispuesto: a. - dejar sin efecto la condena civil asi como todas sus consecuencias; $b$. - publicar un resumen oficial de la sentencia, yc.-entregar las sumas reconocidas en dicho fallo.

48 HitTers, Juan Carlos, Control de convencionalidad. Adelantos y retrocesos, Editorial Porrúa, Colección Biblioteca Porrúa de Derecho Procesal Constitucional No 111, México, 2015. 
Uno de los puntos nucleares del fallo analizado es que el cuerpo interamericano no tiene competencia para ordenar a los órganos jurisdiccionales de la más alta jerarquia del derecho interno "dejar sin efecto" sus sentencias, y otro de los argumentos basilares radica -según la mayoría (cons. $16^{\circ}$ ) - en que dejar sin efecto una sentencia pasada en autoridad de cosa juzgada es uno de los supuestos en los que la restitución "resulta juridicamente imposible a la luz de los principios centrales del derecho público argentino".

Entre esos postulados inconmovibles se halla -dice el pronunciamientoel "carácter de órgano supremo" de la Corte de Justicia de la Nación. De ahí entonces que, según esta opinión -que no compartimos-, el mismo no puede recibir "órdenes" internacionales; se trata de una "esfera de reserva soberana" (art. 27 Constitución Nacional) a la cual los tratados internacionales deben ajustarse. Esta pauta es totalmente ratificada por el ministro Rosatti ${ }^{49}$ (cons. $4^{\circ}, 5^{\circ}$ y $6^{\circ}$ ).

Parece fácil deducir de lo antes contextualizado que los fundamentos de la mayoría, sumados a los del juez Rosatti, se apontocan en alguna medida en la disidencia del Dr. Fayt en el caso Espósito ${ }^{50}$ (cons. $13^{\circ}$ ), que a su vez venían instalados en Arancibia Clavel${ }^{51}$. Es decir que el ex ministro supremo enlaza los argumentos de "Arancibia Clavel" y de "Espósito", que en definitiva -eso creemos- florecen en el asunto "Ministerio de Relaciones Exteriores" (Fontevecchia) aquí comentado 52 .

49 Sostiene este ministro -citando a Joaquín V. González- que un tratado no puede alterar la supremacía de la Constitución Nacional, por ejemplo, cambiando la forma de gobierno, suprimiendo una provincia, ni suprimir o disminuir en forma alguna las garantías constitucionales creadas para hacerlos efectivos “... en cuanto a la Constitución Nacional sea lo que es, el artículo 27 tiene para la Nación significado singular en el derecho internacional” (cita textual de Joaquín V. González).

50 Dijo allí que "... el artículo 27 de la Constitución Nacional debe ser ponderado como una norma de inestimable valor para la soberanía de un país, en particular, frente al estado de las relaciones actuales entre los integrantes de la comunidad internacional. Por ello, la interpretación propiciada preserva -ante las marcadas asimetrías económicas y sociales que pueden presentar los Estados signatarios de un mismo tratado-, el avance de los más poderosos sobre los asuntos internos de los más débiles; en suma, aventa la desnaturalización de las bases mismas del Derecho Internacional contemporáneo pues procura evitar que detrás de un aparente humanismo jurídico se permitan ejercicios coloniales de extensión de la soberanía"; aquí cita su disidencia en el caso "Arancibia Clavel, considerando $16^{\circ "}$.

51 CSJN. Arancibia Clavel, Enrique Lautaro s/ homicidio y asociación ilícita -causa No 259-, sentencia de 8 de marzo de 2005.

52 Repárese, y esto creemos que es de gran importancia, que en ambos expedientes donde vota el Dr. Fayt en disidencia se tratan cuestiones "penales", mientras que aquí estamos haciendo referencia a asuntos "civiles". 
Sin perjuicio de que el Dr. Rosatti pone énfasis en sostener que los tratados internacionales están en una escala inferior a la Constitución Nacional -por lo que deduce que no puede cumplirse la orden de la Corte IDH de "dejar sin efecto" el fallo de la Corte Nacional del 2011. Aclara -y en esto estamos totalmente de acuerdo- (en el cons. $8^{\circ}$ de su voto), que en un contexto de "diálogo jurisprudencial" debe procurarse mantener la convergencia decisional entre los organismos con competencia para dirimir conflictos en los ámbitos nacional e internacional 'reconociendo a la Corte Interamericana de Derechos Humanos como último intérprete de la CADH (art. 62, puntos I y III CADH)' y a la Corte Suprema de Justicia de la Nación como último intérprete de la Constitución Nacional Argentina (arts. 116 y 117 de la Constitución Nacional)". Por ello concluye en que la sentencia Fontevecchia está "prácticamente cumplida"53, lo único que no es posible es revocar -aduna- el decisorio nacional.

En síntesis, de los basamentos centrales del fallo mayoritario podemos llegar a las siguientes conclusiones: 1.- no es competencia de la Corte Interamericana "dejar sin efecto" un fallo de la más alta autoridad judicial del país; 2.- tal mecanismo restitutivo no está contemplado en el artículo 63.1 de la $\mathrm{CADH}$, ni siquiera fue pensado en los trabajos preparatorios de la Convención Americana; 3.- la competencia de la Corte del Pacto está "limitada" sobre la base del principio de subsidiariedad. Esta comprensión - dice la CSJN - está abrazada enfáticamente por el Tribunal Europeo de Derechos Humanos en sus doctrinas del margen de apreciación nacional; 4.- el cimero tribunal regional no revisa los pronunciamientos domésticos; 5.- dejar sin efecto equivaldría a "revocar"; 6.- la integrum restitutio -el remedio restitutivo-, vista por la Corte IDH como forma de reparación, sólo funciona cuando es posible llevarla a cabo, ya que, por ejemplo, si la víctima muere, hay que elegir otra vía de reparación; 7.- la cualidad de "órgano supremo" de la CSJN forma parte de los principios de derecho público a los que hace referencia el artículo 27 de la Constitución Nacional. El constituyente - añade- ha consagrado en la citada norma ${ }^{54}$ una esfera de reserva soberana, a la cual los tratados internacionales deben ajustarse. Por ello no es posible hacer prevalecer automáticamente -sin escrutinio alguno- el derecho internacional sobre la Carta Magna; 8.- la CSJN no niega obligatoriedad al pronunciamiento del tribunal internacional, sólo que en este caso carece de competencia; 9.- por

53 En esto -como veremos- no estamos de acuerdo.

54 Citando a Joaquín V. González, como ya vimos. 
último, tanto la mayoría como el voto coincidente del Dr. Rosatti entienden que la cuestión debe resolverse en un contexto de diálogo jurisprudencial partiendo de la base -para dirimir conflictos en los ámbitos nacional e internacional-, de que la Corte IDH es el último intérprete de la $\mathrm{CADH}$ (artículo 62, puntos 1 y $3 \mathrm{CADH}$ ), y que la CSJN es el último intérprete de la Constitución Nacional (artículos 116 y 117).

\section{RÉPLICA}

\section{A. Tratados clásicos y tratados sobre derechos humanos}

Antes que nada conviene repetir que no coincidimos con todos los argumentos del pronunciamiento local de la mayoría, pues los principios de derecho público, a los que según el mismo deben conformarse los tratados, no fueron pensados para esta época donde imperan los "tratados sobre derechos humanos", sin perjuicio -claro está- de lo dispuesto en la Reforma de 1994, esencialmente en el artículo 75 inciso $22^{\circ}$ de ese ordenamiento, que obviamente los tuvo en cuenta.

Es importante hacer una marcada dicotomía entre los tratados clásicos y los que reglamentan internacionalmente los derechos humanos, aunque que se aprecian notables diferencias entre los tradicionales y los atinentes a las libertades del hombre. En efecto, éstos tienen un contenido que apunta a una garantía mínima cuyo desarrollo progresivo casi siempre se prevé; además no están restringidos por la contraposición del interés de los signatarios, ni rige para ellos el principio de reciprocidad entre los derechos y obligaciones contraídas. En este tipo de instrumentos, el destinatario es el ser humano, y los Estados en estos casos no tienen un interés propio, puesto que apuntan a mantener las prerrogativas del ser humano. Por otra parte, la mayoría de ellos crea para los gobiernos obligaciones erga omnes, y además no se aplican las reglas generales sobre "reservas", que imperan para los tratados clásicos ${ }^{55}$.

Digamos que el objeto y fin de los documentos abordados en este apartado son los derechos fundamentales del hombre, y no quedan sin efecto-como los otros- en caso de incumplimiento de las partes. Uno de sus rasgos definidores es que se le reconoce al individuo la calidad de sujeto de derecho internacional.

Siendo ello así, fácil es colegir que, cuando el voto mayoritario habla de la fórmula argentina, de la reserva de soberania, y de los tratados que estén en confor-

55 HitTters, Juan Carlos, control de convencionalidad. Adelantos y Retrocesos, ob. cit., Capítulo XI, p. 108. 
midad con los principios del derecho público argentino establecidos en el artículo 27 de la Constitución Nacional (cons. 16, 17 y 18), creemos que el razonamiento no se autoabastece, ya que existe una notable diferencia entre aquellos tratados y los que regulan los derechos humanos ya aludidos.

En efecto, la Carta Magna de 1853-1860 aludía a los tratados de paz y comercio de aquel momento, que nada tienen que ver con las convenciones internacionales tuitivas de las potestades y libertades del hombre ${ }^{56}$.

\section{B. Kompetenz kompetenz}

El fallo de la CSJN considera que la entidad judicial interamericana no tiene "competencia" para dejar sin efecto sentencias domésticas que han pasado en autoridad de cosa juzgada.

Sin embargo, como se infiere de un postulado clásico del derecho procesal, es el cuerpo de la más alta jerarquía judicial quien tiene la aptitud de juzgar sobre su propia competencia.

Si bien es cierto que la Conferencia Especializada ${ }^{57}$ eliminó la potestad que surgía del artículo 51 del Proyecto de la Comisión (a diferencia de su homónima europea $^{58}$, que la contempló), la Convención Americana nada dijo sobre esta temática, aunque de su contexto se infiere tal posibilidad, por ser la Corte IDH el único órgano jurisdiccional del modelo regional. Además -como expresa Buergenthal-, tal laguna fácilmente puede llenarse sosteniendo que es regla del derecho internacional generalmente reconocido que es incumbencia del más alto cuerpo de justicia sentenciar sobre su propia competencia, lo que los alemanes llaman kompetenz kompetenz. Es que decidir esto, al igual que interpretar el estatuto y

\footnotetext{
56 En este sentido sostiene con acierto Midón que aquel precepto aludía a los tratados de paz y comercio propios de ese contexto histórico: “... paz en cuanto antítesis de guerra y comercio en la más pura acepción de compraventa de mercancías", Midón, Mario, El alzamiento de la corte ante una sentencia de la CIDH (citado por Gil Domínguez, Andrés, "Estado constitucional y convencional de derecho y control de convencionalidad", La Ley, Boletín del 3.04.2017).

57 Conferencia Especializada Interamericana sobre Derechos Humanos, Secretaría General, Organización de los Estados Americanos, OE/Ser.K/XVI/1.2., San José, Costa Rica, 7-22 de noviembre de 1969. Véase HitTers, Juan Carlos, Control de convencionalidad, ob. cit., capítulo XI, p. 108.

58 El artículo 49 del Convenio de Roma dice: "En caso de que sea discutida la competencia del Tribunal, éste decidirá sobre la misma". Tal criterio había sido instalado por el Estatuto de la Corte Internacional de Justicia (BuERgenthal, Thomas, Las convenciones europeas y americana: algunas similitudes y diferencias; en La Convención Americana sobre Derechos Humanos, Organización de los Estados Americanos, Washington, D.C. 1980 , p. 121).
} 
el reglamento que rigen su organización y funciones, constituye una atribución esencial de la independencia que debe poseer todo órgano convencional.

Así lo ha hecho presente la Corte IDH al parar mientes en que, como todo cuerpo con funciones jurisdiccionales, tiene el poder inherente a sus atribuciones de determinar el alcance de su propia competencia, ya que el reconocimiento de la misma por el Estado presupone la admisión del derecho del tribunal a resolver cualquier controversia relativa a su jurisdicción, de acuerdo con lo dispuesto en el art. 62.1 de la Convención Americana ${ }^{59}$. En tal sentido, ha considerado que no puede dejar a la voluntad de los países la determinación de cuáles hechos se encuentran excluidos de su competencia ${ }^{60}$.

De ello fácilmente cabe colegir que, cualquiera sea el argumento de la corte argentina, la potestad de decidir la competencia de la interamericana es exclusiva del tribunal con asiento en Costa Rica ${ }^{61}$.

\section{Vuelta al dualismo}

Desde otro punto de vista, como bien señalan algunos autores, al no darle a los tratados internacionales la verdadera jerarquía constitucional que poseen se vuelve

59 Corte IDH, casos: Baena Ricardo, sentencia de 28 de noviembre de 2003, cit., párr. 68; del Tribunal Constitucional, sentencia de 24 de septiembre de 1999, párr. 33; Ivcher Bronstein, sentencia de 24 de septiembre de 1999, párr. 34; Niñas Yean y Bosico, sentencia de 8 de septiembre de 2005, párr. 78; de las Hermanas Serrano Cruz, sentencia de 23 de noviembre de 2004, pátr. 74; Almonacid Arellano, sentencia de 26 de septiembre de 2006, párr. 45, García Prieto, sentencia de 20 de noviembre de 2007, párr. 41, Radilla Pacheco, sentencia de 23 de noviembre de 2009, párr. 14.

60 La aplicación de esta potestad se observa en el caso Vélez Loor, en el que se había cuestionado la competencia de la Corte IDH para conocer de violaciones a la Convención contra la Tortura. Por ello expresó allí que "Si bien el articulo 8 de la Convención contra la Tortura (este precepto dispone respecto a la competencia para aplicarla que una vez agotado el ordenamiento jurídico interno del respectivo Estado y los recursos que éste prevé, el caso podrá ser sometido a instancias internacionales cuya competencia haya sido aceptada por ese Estado' al que se atribuye la violación de dicho tratado) no menciona explícitamente a la Corte Interamericana, este Tribunal se ha referido a su propia competencia para interpretar y aplicar dicha Convención, en base a un medio de interpretación complementario, como son los trabajos preparatorios, ante la posible ambigüedad de la disposición", Corte IDH, casos Vélez Loor vs. Panamá, cit., párr. 33, y González y otras ("Campo Algodonero"), cit., párr. 51.

61 Desde esta vertiente ha dicho el profesor Nogueira Alcalá que en Chile las reglas derivadas de la Convención Americana son normas internacionales incorporadas al derecho interno, por lo cual deben ser aplicadas por la jurisdicción local como fuente del ordenamiento jurídico del país, además de ser normas internacionales cuyo intérprete supremo es la Corte de San José. Nogueira Alcalá, Humberto, Los desafios de la sentencia de la Corte interamericana en el caso Almonacid Arellano, Revista Ius et Praxis, 12(2):363-364, 2006. 
a la teoría dualista ${ }^{62}$-por oposición a la monista-, apareciendo generalmente una serie de conflictos entre ambos modelos en relación con la "autonomía" de cada uno y con la "prioridad" o "prelación" que le corresponde.

\section{El principio de subsidiariedad}

Sostiene el voto mayoritario, en el asunto comentado, que impera en el modelo regional el principio de subsidiariedad, criterio que compartimos ampliamente (considerando $8^{\circ}$ ). Pero de ello no puede inferirse de ninguna manera que en el sector nacional es posible resolver los juicios sin acatar los Pactos Internacionales sobre Derechos Humanos y la jurisprudencia de la Corte Interamericana ${ }^{63}$.

La premisa de la $\mathrm{CADH}$ es que los países deben concluir sus problemas dentro de sus fronteras, pero a sabiendas de que, si se equivocan, las actuaciones pueden llegar -vía la Comisión IDH-a la propia Corte, que es -como varias veces dijimosel uiltimo y más genuino intérprete de los tratados a los que el pais se ha plegado64.

Cuando el tribunal cimero nacional, en el voto del Dr. Rosatti, hace referencia al "diálogo", pensamos que una de las formas más contundentes para lograrlo es "armonizando" el derecho nacional y el internacional de los derechos humanos a través de lo que se ha dado en llamar "cláusula de interpretación conforme" 65 (artículos 27,75 inc. $22^{\circ}$ y 108 de la Constitución Nacional y art. 27 de la CADH).

En síntesis, el principio de subsidiariedad tiene en miras que en el ámbito doméstico se concluyen los pleitos (art. 46.1 CADH); el tribunal regional sólo interviene $-\mathrm{y}$ con amplias potestades- cuando no se han respetado las convenciones.

\footnotetext{
62 Abramovich, Victor, Comentarios sobre el "Caso Fontevecchia", 17 de febrero de 2017, CJDHUNLA.

63 HitTers, Juan Carlos, "La responsabilidad del Estado por violación de tratados internacionales", Revista Estudios Constitucionales, Año $5 \mathrm{~N}^{\circ}$ 1, Universidad de Talca 2007, pp. 208 y ss.

${ }^{64} \mathrm{Al}$ respecto, debe recordarse, como lo ha establecido el mencionado cuerpo regional, que "el Estado 'es el principal garante de los derechos humanos de la personas, de manera que, si se produce un acto violatorio de dichos derechos, es el propio Estado quien tiene el deber de resolver el asunto a nivel interno [...], antes de tener que responder ante instancias internacionales como el Sistema Interamericano, lo cual deriva del carácter subsidiario que reviste el proceso internacional frente a los sistemas nacionales de garantías de los derechos humanos'" (Conf. Corte IDH, Caso Acevedo Jaramillo y otros vs. Perú, sentencia de 7 de febrero de 2006, Serie C No 144, párr. 66), Corte IDH, Caso Brewer Carías vs. Venezuela, sentencia de 26 de mayo de 2014. Serie C No 278, Voto Conjunto Disidente de los Jueces Manuel E. Ventura Robles y Eduardo Ferrer Mac-Gregor Poisot, párr. 63.

65 La misma consiste en una técnica hermenéutica por medio de la cual las reglas contenidas en las cartas magnas locales son "armonizadas" con los postulados y principios que surgen de los tratados de derechos humanos. Hablamos de tratados constitucionalizados.
} 
Bajo esta hermenéutica, si bien el fallo analizado habla de "diálogo", no debería haber concluido en que los pronunciamientos de la corte local no pueden ser dejados sin efecto por el tribunal interamericano.

\section{E. Margen de apreciación nacional}

El fundamento del "margen de apreciación nacional", utilizado por la mayoría, nos parece que no puede llegar a resultados tan contundentes. Tiene límites y juega a fondo sólo cuando no hay jurisprudencia de la Corte IDH sobre el tema.

La CSJN señala que el tribunal interamericano no posee carácter de órgano de casación o de apelación, citando en esto un fallo del tribunal regional "Genie Lacayo" 66 . De esa manera liga los conceptos de "margen de apreciación nacional" y de "subsidiariedad" (cons. $10^{\circ}$ ) $^{67}$, deduciendo que la Corte IDH no posee el poder de dejar sin efecto la sentencia de la causa en cuestión porque esto significaría inmiscuirse en el derecho interno (cons. $11^{\circ}$ ).

Uno de los temas más complicados de esta problemática es saber cuál es el margen y qué amplitud tiene $e^{68}$. Tal figura ha sido utilizada -dice nuestra Corte Nacional-por el Tribunal Europeo de Derechos Humanos ${ }^{69}$. La podemos definir como una especie de "deferencia" del cuerpo supranacional hacia las autoridades locales, para que sean éstas las que fallen en determinadas cuestiones, con independencia de los organismos que imponen los tratados internacionales. Ello se da en aquellas hipótesis en las que el cuerpo jurisdiccional internacional "considera" que los judiciales internos están en mejores condiciones para fallar el asunto.

66 Corte IDH, Caso Genie Lacayo vs. Nicaragua, sentencia de 29 de enero de 1997, Serie C No 30.

67 Díaz Crego, María, Margen de apreciación nacionah, en Diccionario Iberoamericano de Derechos Humanos y Fundamentales, Universidad de Alcalá, última actualización: 9.05.2011, (http://diccionario. Pradpi.org/ inicio/indez.php/términos_pub/view/94).

68 Como vimos, ésta es la teoría que manejó el Dr. Fayt en sus votos de Simón, Mazzeo y Bulacio, entre otros.

69 Aunque en puridad de verdad fue la ex Comisión Europea de Derechos Humanos la que hizo expresa referencia a tal corriente, hundiendo sus raíces en la idea del marge d'appréciation, aplicada por el Consejo de Estado francés. Días Grego, ob. cit. 
Por eso pensamos que el campo se "achica" cuando existen criterios o estándares establecidos por la Corte IDH $^{70}$.

De todos modos, lo cierto es que tal cual ya lo expresamos, sería conveniente "flexibilizar" en lo posible esa posición que impone la supremacía convencional o interpretación jerárquica, por el "principio de la coordinación" entre los sistemas nacionales e internacionales y viceversa ${ }^{71}$; esto es lo que ha dado en llamarse diálogo jurisprudencial entre la justicia local y la internacional ${ }^{72}$.

Un ejemplo que ha dado la Corte Interamericana sobre la aplicación del margen de apreciación nacional fue en el caso Castañeda Gutman vs. México ${ }^{73}$, donde "permitió" que la dirección del gobierno y su actividad democrática interior sea competencia exclusiva del Estado mexicano, en ciertos temas electorales ${ }^{74}$.

Sin embargo, en asuntos como el caso "Gelman vs. Uruguay" 75 el cuerpo regional de marras le negó a la Suprema Corte ${ }^{76}$ de ese país la posibilidad de poner en juego el margen de apreciación nacional. Ello ocurrió cuando el tribunal interamericano se ocupó del problema en la supervisión de cumplimiento de sentencia ${ }^{77}$, sosteniendo que ese país debía acatar el fallo dictado por ella.

\footnotetext{
70 Véase García Ramírez, Sergio, El controljudicial interno de convencionalidad, en IUS, Revista del Instituto de Ciencias Jurídicas de Puebla, A.C., Vol. V, núm. 28, diciembre de 2011, Puebla, México.

71 Carpizo, Enrique, El control de convencionalidad y su relación con el sistema constitucional Mexicano. Hacia una simple actividad protectora de los derechos humanos, en Boletín Mexicano de Derecho Comparado, año XLVI, núm. 138, sept.-dic. de 2013, pp. 939-971.

72 Nogueira Alcalá, Humberto, El diálogo jurisdiccional entre tribunales nacionales y la Corte Interamericana de Derechos Humanos en Chile, Ponencia del XXV Congreso Argentino de Derecho Internacional, La Plata, Argentina, organizado por la Facultad de Ciencias Jurídicas y Sociales de las Universidades Nacional de La Plata, Católica de La Plata y Universidad del Este, septiembre de 2013.

73 Sentencia de 6 de agosto de 2008.

74 Carpizo, Enrique, El control de convencionalidad, ob. cit.

75 Corte IDH, Caso Gelman vs. Uruguay, sentencia de 24 de febrero de 2011, Serie C No 221, párrs. 241 a 246.

76 Caso "M.L., J.F.F., O - Denuncia Excepción de Inconstitucionalidad ... IUE -II- 109971/2011". Sentencia de 18.02.2013, por mayoría.

77 Caso Gelman vs. Unuguay, Supervisión de Cumplimiento de Sentencia, Resolución del 20 de marzo de 2013, párrafo 69.
} 
Éste fue un caso muy similar a Fontevecchia-Ministerio ${ }^{78}$, ya que la Corte IDH entendió que la Suprema Corte oriental no había acatado su fallo "Gelman vs. Uruguay".

\section{Consecuencias jurídicas de la FalTa de anulación}

Al haber rechazado la CSJN en el año 2011 la posibilidad de dejar sin efecto su fallo de $2001^{79}$, quedan dos decisorios firmes que encierran una contradicción.

El tribunal cimero argentino había condenado en el año 2001 a los accionados por violación al derecho a la integridad moral, el honor y la intimidad de las personas (artículos 14, 19 y 33 Constitución Nacional; 17 párrs. $1^{\circ}$ y $2^{\circ}$ del Pacto Internacional de los Derechos Políticos y Civiles, y 2 y 3 de la CADH), y a pagar una indemnización a favor del ex presidente Carlos Menem.

La Corte IDH en el 2011 hizo lugar a la demanda contra el Estado argentino y dispuso dejar sin efecto aquella "condena civil" así como todas sus consecuencias. Recuérdese que en la vía doméstica se había dispuesto indemnizar a Carlos Menem, y que el tribunal supranacional dijo que tal reparación era improcedente. Esto implicó que, al haber abonado el Estado la indemnización correspondiente por la sentencia del año 2001, luego, y como consecuencia de ello, tal pago puede verse como un enriquecimiento (sin causa) en virtud de lo dispuesto en el artículo 1794 del Código Civil, lo que podría potenciar al Estado a llevar a cabo la repetición ${ }^{80}$. Lo cierto es que como acabamos de sostener, y pese a la interpretación de la Corte argentina ${ }^{81}$, la contradicción sería: por un lado, pagarle a Menem (fallo

\footnotetext{
78 Similar pero no idéntico, porque la Corte uruguaya, a diferencia de la argentina, le había negado valor vinculante al pronunciamiento de la Corte Interamericana sobre el tema.

79 CNJN, 324:2985, del 25.09.2001 (cit.).

80 Como dice Palacio de CaEtro, "aquí se torna importante indagar acerca de un resarcimiento por parte del Estado nacional debido a sumas pagadas a un tercero que finalmente se benefició. A resultar condenas patrimoniales aquél debe tener la posibilidad de resarcirse, pero tal contingencia se torna imposible al mantenerse la autoridad de la cosa juzgada interna en el caso 'Menem...', cuyos efectos fueron dejados sin efecto y anulados por la Corte Interamericana de Derechos Humanos", Palacio de CaEIRo, Silvina, "El cumplimiento de las sentencias de la Corte Interamericana de Derechos Humanos", Revista La Ley 8.03.2017, p. 21.

81 Véase voto del Dr. Maqueda, cons. $6^{\circ}$.
} 
CSJN 2001), y, por otra parte, el Estado nacional debe entregar las sumas reconocidas en el fallo regional ${ }^{82}$.

Si esto se acata a pie juntillas, el Estado estaría haciendo un pago indebido.

\section{LA CONTROVERTIDA INTERPRETACIÓN DEL TRIBUNAL SUPREMO NACIONAL}

Este órgano judicial llevó a cabo una forzada interpretación del Sistema Interamericano -creemos- para llegar a la conclusión de que no puede ser obligado a "dejar sin efecto" los pronunciamientos que él emite.

A nuestro modo de ver, las reglas regionales no necesitan ningin tipo de interpretación, pues el artículo 63.1 es muy claro al sostener que, cuando hubo violación, la Corte IDH puede disponer que se garantice al lesionado el goce de su derecho o libertad vulnerados, y si ello fuera procedente, que se reparen las consecuencias y el pago de una indemnización. Y justamente en la frase "que se reparen las consecuencias" está incluida la posibilidad de "dejar sin efecto" un decisorio local (in claris non fit interpretatio).

Ello así, pues "anulando" o "revocando" una sentencia local deficitaria se reparan las consecuencias y se puede indemnizar a la víctima.

No obstante eso - y a todo evento-, si fuese imprescindible una hermenéutica, nos parece que la que ejercitó la CSJN es muy discutible, y creemos que los casos que cita no se acomodan al caso analizado.

Como sabemos, se parte de la base del artículo 27 de la Constitución Nacional para llegar -a través de los artículos 31 y 32 de la Convención de Viena sobre el Derecho de los tratados- al resultado de la imposibilidad de revocar o anular, por mandato de la Corte IDH, los fallos domésticos.

Vemos que aquí también hay un vacío argumental en nuestro tribunal argentino, porque si bien es cierto que la Convención de Viena ilumina el derecho de los tratados, no lo es menos que ese cuerpo normativo apunta especialmente a los convenios entre países, y no específicamente a los atinentes a los derechos humanos, que, como lo expresamos, precisan de una interpretación muy afinada teniendo en cuenta la materia de la que se ocupan.

Desde esa vertiente pensamos que al "cambiar" la Corte nacional su anterior jurisprudencia, se ha inaplicado el principio de no regresividad, el cual establece

82 Conforme a lo dispuesto en la sentencia regional y en la última supervisión de la Corte, de 29.11.2016, Punto Resolutivo 1.d. 
que no debe crearse o modificarse normativa o postulados que vengan a reducir la pantalla protectora ya existente.

Esto es por vía del principio, pues, obviamente, no significa que un tribunal no pueda alterar sus criterios cuando lo considerare necesario; pero debe tenerse mucho cuidado en el campo de derechos humanos.

En efecto, si tenemos en cuenta que ese cuerpo jurisdiccional en Kimel abrió la posibilidad de "dejar sin efecto sus sentencias", resulta que ahora ha puesto en discusión ese postulado, lo que implica una regresión (no regresividad).

En el considerando $12^{\circ}$ dice el tribunal supremo argentino que dejar sin efecto una sentencia pasada en autoridad de cosa juzgada importa acudir a un mecanismo restitutivo que no se encuentra previsto por el texto convencional, agregando que el análisis "textual" -gramatical- es fundamental, puesto que la letra de los tratados determina los límites de la competencia remedial.

Deduce del artículo 31 de la Convención de Viena que los organismos internacionales poseen competencia limitada, de la manera prescrita en los instrumentos que los han constituido y carecen de jurisdicción para seleccionar los remedios que quieran, y por lo que, a tenor literal del artículo 63.1 de la Convención, se entiende que el tribunal regional no está en condiciones de disponer tal "amputación" a una sentencia dictada en sede nacional ${ }^{83}$.

Observando la problemática interpretativa desde la ventana del Pacto de San José y de la jurisprudencia interamericana, debemos reiterar que cuando la Corte doméstica se niega a modificar su propio fallo achica la tutela internacional dándole prioridad a una norma interna (artículo 27 de la Constitución Nacional) ${ }^{84}$, en infracción al artículo 27 de la Convención de Viena, ya aludida.

La clave de bóveda para evitar desenfoques es no olvidar la doctrina legal del propio tribunal del sistema regional, donde se sostiene que, para interpretar una convención sobre derechos humanos, hay que tener en cuenta tres elementos fundamentales: 1. el propio tratado, 2. el ius cogens, y 3.- la jurisprudencia de la Corte IDH.

83 Cons. $13^{\circ}$, voto de la mayoría.

84 Piza Escalante, su voto separado en Corte Interamericana de Derechos Humanos, Opinión Consultiva OC-4/84 del 19 de enero de 1984. 
Estas doctrinas fueron ratificadas por las opiniones consultivas OC-3/8385 y OC-8/8786, donde -ya lo adelantamos- se llega a la conclusión de que el sistema de la Convención Americana está dirigido a reconocer derechos y libertades a las personas y no a facultar a los Estados para hacerlo. Cada uno de los convenios sobre derechos humanos debe analizarse teniendo como base el objeto y fin de los mismos. Por ello dijimos que nuestro tribunal supremo ha desinterpretado lo dicho por la Corte IDH en "Perozo", "Genie Lacayo", "Aloeboetoe" y "Blake" 87 , entre otros.

Veamos, cuando la CSJN trae a colación los casos "Aloeboetoe" y "Blake" para llegar a la conclusión que "el mecanismo restitutivo no está regulado en la $\mathrm{CADH}$, importa poner de relieve que en ambos asuntos la situación fáctica era muy distinta a la aqui analizada, pues en sendos precedentes la restitutio no fue posible, pues las víctimas habían fallecido.

El primero de ellos abordaba, entre otras, la cuestión de la desaparición forzada de Nicholas Blake ${ }^{88}$, de ahí que la "revisión" no era factible, aunque sí la indemnización compensatoria a los familiares.

En el caso "Aloeboetoe" 89 se trataba de cinco campesinos que vivían alejados de los centros urbanos -cimarrones se dice en el fallo- que fueron asesinados por las fuerzas militares de Surinam. Allí tampoco fue posible la resitutio in integrum ${ }^{90}$, por eso se indemnizó a los deudos.

$\mathrm{La} \mathrm{CSJN}^{91}$, haciendo referencia al caso Perozo ${ }^{92}$, sostiene que el sistema interamericano se autodefine como subsidiario y que el cuerpo jurisdiccional regional no constituye una "cuarta instancia" que revisa o anula fallos internos. Si bien ello es cierto, creemos que el citado expediente contra Venezuela tampoco es cabal-

85 Corte IDH, Restricciones a la pena de muerte (arts. 4.2 y 4.4 Convención Americana sobre Derechos Humanos), Opinión Consultiva OC-3/83 de 8 de septiembre de 1983, Serie A No 3, párrafo 48.

86 Corte IDH, El habeas corpus bajo suspensión de garantías (arts. 27.2, 25.1 y 7.6 Convención Americana sobre Derechos Humanos), Opinión Consultiva OC-8/87 de 30 de enero de 1987, Serie A No 8, párrafos 4-21.

$87 \mathrm{CSJN}$, fallo "Ministerio del Interior..." (cit.), cons. $15^{\circ}$.

88 Corte IDH, Caso Blake vs. Guatemaia, Sentencia de 24 de enero de 1998, Serie C No 36.

89 Corte IDH, Caso Aloeboetoe y otros vs. Surinam, Sentencia de 4 de diciembre de 1991, Serie C No 11.

90 Dijo la Corte IDH que en lo que hace al derecho a la vida no es posible devolver su goce a las víctimas. En estos casos la reparación debe asumir otras formas restitutivas, como la reparación pecuniaria (Corte IDH. Caso Aloeboetoe y otros vs. Surinam, Sentencia de 10 de septiembre de 1993. Serie C No 1e, párrs. 49 y 50 ).

91 Considerando $8^{\circ}$.

92 Corte IDH, Caso Perozo y otros vs. Venezuela, Sentencia de 28 de enero de 2009, Serie C No 195, párrafo 64. 
mente aplicable al caso que nos ocupa, porque allí la Corte IDH no pudo juzgar el fondo pues no se habian agotado, en ese momento, los recursos internos (artículo 46.1), ya que el Estado no tenía concluidas las investigaciones (civiles y penales) en sede local93. Por eso dice la Corte IDH que ella sólo interviene "después" de que el país ha tenido la oportunidad de conocer ${ }^{94}$.

Obsérvese que en "Ministerio-Fontevecchia" las actuaciones concluyeron en Argentina, fueron abordadas luego en la Comisión Interamericana y posteriormente falladas por la Corte regional, mientras que en Perozo - como ya se dijofaltaban una serie de investigaciones domésticas y por ende el proceso no estaba concluido ${ }^{95}$ (véase CSJN, Ministerio, cit., cons. $8^{\circ}$ ).

Algo similar ha sucedido en Genie Lacayo ${ }^{96}$, donde finalmente el Estado nicaragüense fue condenado por obstaculizar la investigación policial y por una demora no razonable en el proceso (artículos 8.1 y 1.1 de la $\mathrm{CADH}$ ). Aquí la investigación -como en "Perozo" - no habia sido concluida", por ello expresó

93 Para entender en profundidad este expediente, que cita la Corte argentina como fundamento de su decisión, conviene conocer las circunstancias fácticas. En efecto, los hechos se refieren a una serie de actos y omisiones, ocurridos entre octubre de 2001 y agosto de 2005, consistentes en declaraciones de funcionarios públicos, actos de hostigamiento, agresiones físicas y verbales, y obstaculizaciones a las labores periodísticas, cometidos por agentes estatales y particulares en perjuicio de 44 personas vinculadas al canal de televisión Globovisión, entre ellas figuran periodistas, personal técnico asociado, empleados, directivos y accionistas. Corte IDH, Caso Perozo (cit.), párr. 64.

94 Corte IDH, Caso Perozo (cit.), párrs. 65 a 74.

95 Por eso la Corte dijo que en el futuro "... El Estado debe conducir eficazmente y dentro de un plazo razonable las investigaciones y procesos penales abiertos a nivel interno que se encuentran en trámite, así como los que se abran en lo sucesivo, para determinar las correspondientes responsabilidades por los hechos de este caso y aplicar las consecuencias que la ley prevea...", véase Corte IDH, Caso Perozo (cit.), puntos resolutivos, párr. 426.11.

96 Los hechos ocurrieron el 28 de octubre de 1990. Jean Paul Genie Lacayo, de 16 años de edad y residente en la ciudad de Managua, se dirigía en automóvil a su domicilio en el reparto Las Colinas. Cuando conducía en la carretera se encontró con una caravana de vehículos con efectivos militares, quienes, al ver que los trataba de sobrepasar, le dispararon con sus armas. Luego de ello, Jean Paul Genie Lacayo fue abandonado en la carretera y murió de shock hipovolémico a consecuencia de la hemorragia. Sus familiares presentaron una serie de recursos ante instancias administrativas, policiales, judiciales y militares, todos ellos dirigidos a investigar y sancionar a los responsables de la muerte de Jean Paul Genie Lacayo. No obstante, existieron numerosos obstáculos en la investigación, y no se llegó a identificar y sancionar a los autores (Corte IDH, Caso Genie Lacayo vs. Nicaragua, Sentencia de 29 de enero de 1997, Serie C No 30).

97 Por eso señaló que "... Finalmente de acuerdo con el derecho internacional general, la Corte Interamericana no tiene el carácter de tribunal de apelación o de casación de los organismos jurisdiccionales de carácter nacional; sólo puede en este caso, señalar las violaciones procesales de los derechos consagrados en la Convención que hayan perjudicado al seńor Raymond Genie Peńalba, que es el afectado en este asunto, pero carece de competencia para subsanar dichas violaciones en el ámbito interno, lo que corresponde hacer, 
que la Corte supranacional ${ }^{98}$ que “... carece de competencia para subsanar (...) violaciones en el ámbito interno..." 99 .

En síntesis, digamos por un lado que el art. 63.1 de la CADH es muy claro, y no hacía falta más que aplicarlo. Si hubo violación, la Corte IDH debe disponer que "se deje sin efecto" el fallo doméstico.

Por otro lado, si a todo evento se necesitaba una interpretación, no es pertinente partir sólo de la "letra" (mirada gramatical) de la Convención de Viena (arts. 31 y 32) ni acudir a los Trabajos Preparatorios del Pacto de San José100 (véase CSJN, Ministerio, cit., cons. $12^{\circ}$ ), más correcto hubiese sido ejercitar la interpretación evolutiva de los tratados sobre derechos humanos que ha hecho el cuerpo judicial de la región (arts. 26 y 29 de dicho instrumento y opiniones consultivas 3, 8 y 9 de la Corte IDH).

\section{IMPOSIBILIDAD DE INCUMPLIR UN FALLO DE LA Corte IDH. El caso "Radilla Pacheco"}

Un ejemplo de lo que venimos marcando lo tenemos en los Estados Unidos de México cuando la Corte Interamericana, en el caso Radilla Pachecho ${ }^{101}$, condenó a ese país por la violación de varios derechos consignados en la $\mathrm{CADH}$, ordenando reformar el artículo 57 del Código de Justicia Militar, referente a la imposibilidad de juzgar a los civiles en dicho fuero ${ }^{102}$. Tal apertura ha implicado

\footnotetext{
según se ha expresado anteriormente, a la Corte Suprema de Justicia de Nicaragua al resolver el recurso de casación que se encuentra pendiente...", Corte IDH, Caso Genie Lacayo (cit.), párr. 94.

98 Corte IDH, Caso Genie Lacayo (cit.), párr. 94.

99 Contra ese fallo se interpuso un recurso de revisión que fue desestimado por la Corte Interamericana, pero ahí sostuvo en un voto disidente el juez Antonio Cançado Trindade: "... Cuando la Corte establece la violación de una o más disposiciones de la Convención, surge la obligación del Estado de cumplir con el fallo de la Corte, a la cual corresponde el derecho del individuo demandante de requerir que su fallo sea cumplido", Corte IDH, Caso Genie Lacayo, 13 de septiembre de 1997, párr. 26 in fine.
}

100 La Conferencia Especializada se celebró en San José, Costa Rica, en noviembre de 1969, cuando todavía ni siquiera funcionaba -obviamente- la Corte IDH. Aunque en dichas sesiones se contempló -como ya pusimos de relieve-, después no se reflejó expresamente en el Pacto. Véase Conferencia Especializada Interamericana sobre Derechos Humanos, Secretaría General, Organización de los Estados Americanos (cit.).

101 Corte IDH, Caso Radilla Pacheco vs. México, Sentencia de 23 de noviembre de 2009, Serie C No 209.

102 Corte IDH, Caso Radilla Pacheco vs. México, Supervisión de Cumplimiento de Sentencia, Resolución de la Corte IDH, 19 de mayo de 2011, párr. 58. 2. c). Dijo allí que el país debía "adoptar, en un plazo razonable, las reformas legislativas pertinentes para compatibilizar el artículo 57 del Código de Justicia Militar 
que esa nación reformara su propia Carta Magna nacional ${ }^{103}$, incluyendo en su artículo $1^{\circ}$ la problemática de los derechos humanos ${ }^{104}$.

La Suprema Corte, al analizar el pronunciamiento condenatorio, aceptó el control difuso de "constitucionalidad" y también la inspección difusa ${ }^{105}$ de "convencionalidad"106.

Quedó en claro que la sentencia del tribunal regional es obligatoria para México $y$, por ende, debe ser cumplida en su totalidad.

Como expresa Ferrer Mac-Gregor ${ }^{107}$ "la Suprema Corte de Justicia al decidir sobre el cumplimiento del caso Radilla Pacheco el 14 de julio de 2011 y que el propio presidente de dicho tribunal calificó como un asunto "histórico", realizó interpretaciones constitucionales de gran calado para el sistema jurídico mexicano, apoyándose en gran medida en los nuevos contenidos normativos del vigente

con los estándares internacionales en la materia y con la Convención Americana sobre Derechos Humanos (punto resolutivo décimo y considerandos 20 a 22)".

103 Véase el libro de los autores Ferrer Mac-Gregor, Eduardo; Silva García, Fernando, El caso Castañeda Gutman ante la Corte Interamericana de Derechos Humanos, Editorial Porrúa México-Universidad Nacional Autónoma de México, año 2009; allí se estudia en profundidad el asunto de referencia.

104 En su artículo 1º dispone: "En los Estados Unidos Mexicanos todas las personas gozarán de los derechos humanos reconocidos en esta Constitución y en los tratados internacionales de los que el Estado Mexicano sea parte, así como de las garantías para su protección, cuyo ejercicio no podrá restringirse ni suspenderse, salvo en los casos y bajo las condiciones que esta Constitución establece [...]. Las normas relativas a los derechos humanos se interpretarán de conformidad con esta Constitución y con los tratados internacionales de la materia favoreciendo en todo tiempo a las personas la protección más amplia [...]. Todas las autoridades, en el ámbito de sus competencias, tienen la obligación de promover, respetar, proteger y garantizar los derechos humanos de conformidad con los principios de universalidad, interdependencia, indivisibilidad y progresividad. En consecuencia, el Estado deberá prevenir, investigar, sancionar y reparar las violaciones a los derechos humanos, en los términos que establezca la ley [...]. Está prohibida la esclavitud en los Estados Unidos Mexicanos. Los esclavos del extranjero que entren al territorio nacional alcanzarán, por este solo hecho, su libertad y la protección de las leyes [...]. Queda prohibida toda discriminación motivada por origen étnico o nacional, el género, la edad, las discapacidades, la condición social, las condiciones de salud, la religión, las opiniones, las preferencias sexuales, el estado civil o cualquier otra que atente contra la dignidad humana y tenga por objeto anular o menoscabar los derechos y libertades de las personas" (Constitución Política de los Estados Unidos Mexicanos de 5 de febrero de 1917, modificada el 10 de junio de 2011, publicada en el DOF el 10 de junio de 2011).

105 De ello resulta que ahora todos los jueces de México deben inspeccionar la compatibilidad de las leyes internas con las de la CADH en los asuntos en los que están involucrados.

106 Corte IDH, Caso Cabrera Garcia y Montiel Flores vs. México, Sentencia de 26 de noviembre de 2010, Serie C No 220.

107 Véase el trabajo de Ferrer Mac-Gregor, Eduardo, Interpretación conforme y control difuso de convencionalidad, ob. cit., pp. 163, 339-429. 
artículo $1^{\circ}$ constitucional". Uno de los criterios principales que deriva de dicho asunto es la obligatoriedad de las sentencias condenatorias de la Corte IDH en los temas donde esa nación ha sido parte, por lo que no pueden ser objeto de revisión por el supremo cuerpo judicial del país, ni siquiera cuando se trata de reservas o declaraciones interpretativas formuladas en su momento por el Estado mexicano.

\section{Conclusiones}

Para finalizar y en forma estenográfica queremos poner de resalto que el fallo del supremo tribunal argentino fue elaborado sobre la base de una serie de argumentos muy meditados, empero, respetuosamente, creemos que ha significado para el sistema interamericano un retroceso, pues al limitar el poder rectificatorio de la Corte IDH queda minimizada la tutela que surge de los tratados internacionales a los que el país se ha adherido. Ello así, habida cuenta de que, al desconocer la competencia de ese cuerpo jurisdiccional de la región, se ha vuelto de alguna manera al dualismo, y además se ha afectado el principio de no regresividad.

El tribunal había reconocido hasta ahora la jurisdicción completa de la Corte con asiento en San José; empero el nuevo pronunciamiento de la mayoría sostiene que, si bien los fallos de aquel cuerpo son obligatorios, estima que en determinadas circunstancias pueden carecer de "competencia" para fallar.

Ello implica que se ha partido de la base de que para acatar en profundidad una sentencia interamericana es preciso llevar a cabo en el orden doméstico una especie de exequatur para examinar si la Corte IDH ha tenido competencia para expedirse.

Lo que aquí está en juego, en puridad de verdad, es una errónea disputa de "competencia" con el organismo regional, que es el que debe resolver la problemática por ser justamente el último intérprete del sistema de la región cuando están en juego normas internacionales (kompetenz-kompetenz) ${ }^{108}$, tal cual ya lo hemos expresado.

El fallo interno sostiene que no puede ordenársele dejar sin efecto sus propios pronunciamientos, porque tal potestad no está contemplada en el artículo 63.1 de la CADH ni en los trabajos preparatorios de la Convención.

\footnotetext{
108 Véase Noguetra Alcalá, Humberto (Los desafios de la sentencia de la Corte interamericana en el caso Almonacid Arellano, ob. cit.), donde señala que “... el juez nacional, al resolver los casos específicos de los cuales conoce en el ámbito de su competencia, puede y debe realizar la interpretación de las normas convencionales incorporadas al derecho interno en clave convencional, debiendo necesariamente tener en cuenta la jurisprudencia de la Corte Interamericana".
} 
Adelantamos ya que del análisis de la citada normativa puede inferirse sin hesitación que ese tribunal regional está expresamente facultado para dejar sin efecto providencias domésticas, ya que, al permitírsele disponer que "se reparen las consecuencias", obviamente se lo potencia para anular las sentencias locales que violen la Convención.

No tenemos que olvidar que los tratados sobre derechos humanos tienen que ser interpretados, como sostiene la doctrina de la Corte IDH, conforme su objeto y fin y que, cuando el Estado se sujeta a este tipo de convenios, debe tener en consideración que alguna manera "limita" su propia soberanía en beneficio del modelo regional.

Resulta imposible -a nuestro entender-invocar lisa y llanamente el postulado del "margen de apreciación nacional", pues el mismo tiene límites que finalmente dependen de la apreciación del último intérprete de los instrumentos internacionales, como lo es la Corte IDH, que no resulta obviamente un organismo extranjero.

El tribunal argentino parte del artículo 27 de la Constitución, sosteniendo que los tratados con las potencias extranjeras deben estar en conformidad con los principios de derecho público establecidos la Carta Magna y, en consecuencia, considera que la jurisdicción supranacional posee una esencia "subsidiaria" que le impide recibir órdenes del cuerpo jurisdiccional interamericano. Esta fundamentación ha sido tomada casi textualmente - sin haberlos citado- de los votos del doctor Fayt en los casos Arancibia Clavel (cons. 15) y de Bulacio-Espósito (cons. 1 a 4), a los que ya hemos aludido.

Pensamos que tal argumentación infringe el artículo 27 de la Convención de Viena sobre el Derecho de los Tratados, pues la base hermenéutica del fallo se apontoca en el concepto de que la Corte Nacional es "suprema" en el ámbito de su competencia. Y esta idea de prelación doméstica se basa en el art. 27 de la Constitución del país, dado que la Corte es "suprema" y tal categoría - dice la sentencia- resulta ser un principio del derecho público de linaje constitucional que no puede infringirse.

Con ese criterio podría dejar de existir el control de convencionalidad y todo el modelo interamericano quedaría en falsete.

Lo que debe quedar bien en claro es que la Corte IDH y todo el esquema regional tienen como fuentes el ius cogens (costumbre internacional) y los tratados sobre derechos humanos, y que tales convenios son de distinta esencia a los que alude el artículo 27 local y que no fueron ni siquiera pensados al redactar dicha regla magna. 
De la forma en que la CSJN juzgó el caso, se advierte que queda plasmada una contradicción, habida cuenta de que el fallo nacional beneficia al ex presidente Menem y lo hace acreedor a una indemnización, mientras que la Corte IDH dice todo lo contrario.

Desde otro ángulo hemos pretendido poner de relieve que la Corte IDH en varios casos, entre ellos Palamara Iribarne, Tristán Donoso, Bueno Alves, Kimel y Herrero Ulloa, ha dispuesto modificaciones a las sentencias locales, decisiones que han sido toleradas por los órganos jurisdiccionales domésticos, incluyendo a la Corte argentina.

El Tribunal Europeo de Derechos Humanos ha seguido las mismas aguas que la Corte IDH en el caso resuelto en el 12 de junio de 2014 (Príncipe de MónacoGrimaldi) ${ }^{109}$, en una temática similar a Fontevecchia sobre libertad de expresión.

El pronunciamiento mayoritario argentino de 2011, Ministerio de Relaciones Exteriores (Fontevecchia), desinterpretó -creemos- la CADH y seguramente cuando la corte regional se ocupe nuevamente del tema -no nos olvidemos que ya realizó dos supervisiones- condenará al Estado.

Coincidimos ampliamente con el voto minoritario del Dr. Maqueda, que sigue una postura que armoniza con sus propios y los precedentes de la CSN, en el sentido de que los fallos interamericanos deben cumplirse a cabalidad sin rodeos, pues, de lo contrario, se incurre en responsabilidad internacional del Estado y en este caso para acatar no hay otro remedio que dejar sin efecto.

109 Dijimos que el tema es muy parecido a Fontevecchia, ya que se trató de un decisorio de la más alta jerarquía jurisdiccional francesa que había condenado a la revista Paris Match por haber revelado la existencia de un hijo extramatrimonial del príncipe de Mónaco. La abogada de esa editora, Marié Chistrine de Persín, remarcó justamente la diferencia que existe entre las personas públicas y quienes no lo son con referencia a la problemática aquí abordada. En un fallo unánime, la Gran Sala del Tribunal Europeo de Derechos Humanos (TEDH) declaró que Francia vulneró la libertad de expresión al condenar a la editorial Hachette Filipacchi y a la directora de la revista "Paris Match", por publicar información de la vida privada del príncipe Alberto de Mónaco. El día 5 de mayo de 2005 la referida revista publicó una entrevista a Nicole Coste, madre soltera de un hijo del príncipe Alberto de Mónaco, agregando en su portada dos fotos del niño junto a su padre y su madre, razón por la cual se la condenó al pago de 50.000 euros al príncipe por concepto de indemnización. Los afectados recurrieron al TEDH argumentando que dicha condena vulneró el derecho a la libertad de expresión, consagrado en el artículo 10 de la Convención Europea de Derechos Humanos. Su recurso fue acogido por la Quinta Sala del TEDH, ante lo cual Francia apeló. En su sentencia, la Gran Sala del TEDH sostuvo en lo grueso que tanto la editorial como la directora de la revista Paris Match contribuyeron a cubrir un asunto de interés público, dada la naturaleza hereditaria de las funciones del jefe de Estado de Mónaco. TEDH, Case of Couderc and Hachette Filipacchi Associés v. France, Application No 40454/07, Estrasburgo, 10 de noviembre de 2015. 
En definitiva, la problemática aquí planteada podría resolverse armonizando el derecho interno con el regional (diálogo) porque, por ejemplo, el pensamiento del jurista Joaquín V. González-vertido hace muchas décadas-no puede invocarse hoy a rajatabla cuando a partir de la reforma de 1994 tenemos una Constitución convencionalizada ${ }^{110}$; por ello hablamos de dialogar, armonizar. La corte del país utilizó esta fraseología, pero finalmente tomó una decisión unilateral, dándole prioridad al derecho doméstico.

Aunque la frase "dejar sin efecto" parezca -y realmente lo es- demasiado fuerte, quizá sería mejor hablar de "adaptar" las sentencias locales a los fallos interamericanos. Técnicamente no es del todo correcto hablar ni de revocación (que implica una impugnación previa) ni de nulificación o invalidamiento, ya que la Corte IHD no es un organismo ad quem respecto a los tribunales locales ${ }^{11}$; se trata de cuerpos jurisdiccionales distintos, que no tienen un relación jerárquica.

De todos modos, no debemos olvidar que, al dejar sin efecto, casi siempre se afectan derechos de terceros, que no fueron parte en el sector interno.

110 SAGÜÉs, Néstor, ¿Puede válidamente la Corte Interamericana obligar a que una corte suprema nacional deje sin efecto una sentencia suya?, Revista El Derecho, 272, 4.04.2017, No 14.155.

111 HitTers, Juan Carlos, Técnica de los recursos extraordinarios y de la casación, Librería Editora Platense, $1^{2}$ Edición 1998, reimpresión 2002, p. 190. 